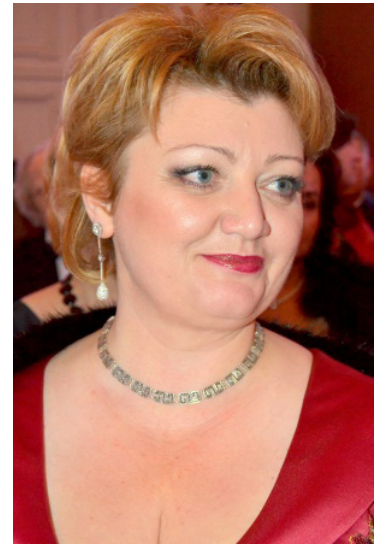

Наталія Мукан, доктор педагогічних наук, професор кафедри педагогіки та інноваційної освіти, Національний університет «Львівська політехніка» (м. Львів, Україна)

\section{Nataliya Mukan,}

Sc.D. (Education), Full Professor, Professor of the Department of Pedagogy and Innovative Education, Lviv Polytechnic National University (Lviv, Ukraine) nataliya.v.mukan@/pnu.ua ORCID ID 0000-0003-4396-3408

\section{Оксана Блавт,}

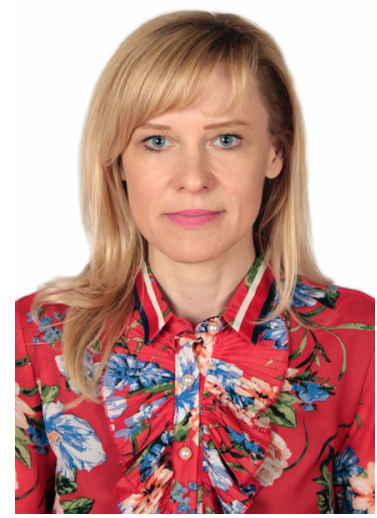

доктор педагогічних наук, доцент, професор кафедри фізичного виховання, Національний університет «Львівська політехніка» (м. Львів, Україна)

\section{Oksana Blavt,}

Sc.D. (Education), Associate Professor, Professor of the Department of Physical Education, Lviv Polytechnic National University (Lviv, Ukraine) oksanablavt@ukr.net ORCID ID 0000-0001-5526-9339

\title{
РОЗВИТОК ОСВІТИ В УКРАЇНІ НА ПОЧАТКУ XXI СТОЛІТТЯ: МОЖЛИВОСТІ ТА ВИКЛИКИ
}

Анотація. У статті розглянуто основні тенденції розвитку освіти початку XXI століття. 3 урахуванням того, що реформування освіти в Україні відбувається за умов модернізаційних процесів у всіх галузях знань, важливим $€$ інноваційний вектор розвитку освітньої галузі. Актуальність дослідження зумовлена об'єктивною необхідністю підвищення ефективності освіти на всіх її рівнях відповідно до сучасного суспільного розвитку задля успішної інтеграції у європейський простір.

Мета дослідження - виявлення основних напрямів розвитку освіти в контексті модернізації на початку XXI століття. В основу дослідження покладено використання комплексу загальнонаукових теоретичних методів: аналізу та синтезу, абстрагування, формалізації.

Обґрунтовано, що позиції й напрями наукового пошуку шляхів розвитку освіти повинні бути спрямовані, поперше, на кардинальну перебудову освітньої галузі, по-друге, на модернізацію цього процесу на основі використання інновацій. За результатами наукової розвідки установлено, що інтеграція модернізаційних процесів в освіті зумовлює появу новітніх підходів до організації освітнього процесу випереджального характеру, які окреслюють перспективний напрям розвитку цієї системи.

Ключові слова: освіта, розвиток, модернізація, інновація, ефективність.

\section{THE DEVELOPMENT OF EDUCATION IN UKRAINE AT THE BEGINNING OF THE XXIST CENTURY: CHANCES AND CHALLENGES}

Abstract. In the article the main trends of education development in Ukraine at the beginning of the XXIst century have been studied. In accordance with education reformation as well as its modernization processes in all spheres the main attention has been paid to its innovative development. The importance of the study is due to the objective need to improve the effectiveness of education at all levels in line with contemporary social development in order to successfully integrate 
into the European space. The purpose of the study is to identify the main directions of the development of education in the context of modernization at the beginning of the XXIst century. The research is based on the use of a set of general scientific theoretical methods: analysis and synthesis, abstraction, formalization.

The scientific research has substantiated that the positions and directions of exploration of educational development pathways should be directed firstly to a radical restructuring of the educational sector, and secondly to the modernization of this process through the use of innovation. An overview and analysis of the priority directions of education modernization are presented. The implementation of them provides development at all its levels, increasing the efficiency of the educational process and obtaining qualitatively new results. The following direction are distinguished: the implementation of interdisciplinary and project approaches, globalization and internationalization of education, intensive development and widespread use of information and communication technologies, taking into account andragogical principles of training, professional mobility of a specialist in the vertical and horizontal dimensions, the insurance of possibilities for lifelong education. It has been found that a significant direction of education development, foreseen by the new educational paradigm, is the application of the type of sociocultural inheritance from the future to the modern, that means the realization of the concept of "lifelong learning", which is transformed into the idea of continuous education. It is determined that one of the priority directions of educational branch modernization is the objective necessity of innovations integration into the process of teaching staff professional training. According to the results of scientific research, it is defined that the integration of modernization processes in education causes the emergence of application of new approaches to the educational process organization of an advanced nature, which outline the future direction of the system development. The results of the study complement the information on the need for active implementation of modernization technologies in the educational process, relevant to modern social development, which is now the most important strategic priority for the sustainable development of education. The implementation of identified trends in education development in the context of modernization is aimed at radical changes that will allow to change and develop the educational process in order to achieve higher results and to formulate a qualitatively different educational practice.

Keywords: education, development, modernization, innovation, efficiency.

\section{ВСТУП}

Постановка проблеми. На початку XXI ст. освіта розглядається як один із ресурсів, що здійснює вагомий вплив на розвиток життєдіяльності суспільства. Зокрема йдеться про такі ії сфери, як економічна, що залежить від підвищення продуктивності праці, здатності людини адаптуватися до нових умов праці, зниження рівня безробіття, розвитку інноваційної діяльності, формування економіки знань загалом (щенко А. Ю.; Кремень В. Г., 2004, с. 37).

Визначальним $€$ значення освіти в соціальному розвитку країни, що спрямований на боротьбу з убогістю, застосування здоров'язбережувальних технологій та охорони навколишнього середовища, розвиток споживацької культури, сприяння успішності пошуку праці, зниження рівня злочинності, формування культури подружнього життя, активну участь у волонтерській діяльності та доброчинності. Беззаперечною є роль освіти в культурному розвитку як окремого індивіда, так і громади, що передбачає наявність знань, умінь і навичок, необхідних для функціонування в полікультурному суспільстві, розвитку культури неперервного навчання, а також у політичному дискурсі, що передбачає активну громадянську позицію людини та її участь у виборчому процесі (Приходько В. В., 2010, с. 21; Mukan N., Noskova M. \& Baibakova I., 2017, с. 125).

Відтак за умов глобальної реструктуризації в усіх галузях освіти та з урахуванням потенціалу її модернізації перехід до нової освітньої парадигми зумовлює актуальність пошуку напрямів розвитку освіти, що передбачає новий рівень ї̈ якості та ефективності. Зазначене і необхідність розв'язання завдань, що визначені теорією й практикою педагогіки у зв'язку з реформуванням системи освіти в Україні, зумовили вибір теми дослідження.

Аналіз останніх досліджень і публікацій. Проблемі розвитку освітньої галузі нині приділяється підвищена увага фахівців, що цілком закономірно, зважаючи на докорінні зміни в економіці, політиці і духовному житті країни, які не могли залишити поза увагою й сферу освіти.

Науковці (Андрущенко В., 2008; Дубасенюк О.А., 2011, с. 136; Харківська А., 2013) єдині в думці, що на сучасному етапі проблема освіти є особливо актуальною, оскільки саме вона дає змогу вчасно та належним чином реагувати на швидкоплинні процеси, що відбуваються в науці, техніці та суспільстві, створює умови для саморозвитку й самореалізації, виступає важливим чинником розбудови демократичного, громадянського суспільства.

Сьогодні в Україні здійснюється реформування освітньої галузі на всіх рівнях: дошкільному, шкільному, на рівні професійної та вищої професійної освіти. Основні напрями цього процесу відображені в нормативно-правовій документації (Іщенко А. Ю.; Національна стратегія розвитку освіти на період до 2021 року, 2013; Наказ Міністерства і науки «Про затвердження Концептуальних засад розвитку педагогічної освіти в Україні та їі інтеграції в європейський освітній простір», 2014), а їхні особливості є предметом наукового диспуту та висвітлюються у наукових працях (Андрущенко В. , 2004, с. 6; Гуревич Р.С., Кадемія М. Ю., Козяр М. М., 2012; Приходько В. В., 2010, с. 77; Харківська А., 2013).

Вивченню різних аспектів означеної проблеми присвячено значну кількість досліджень. Зокрема, проблеми й тенденції функціонування та розвитку освіти досліджено в працях Андрущенко В., Дубасенюк О. А., Кремень В. Г., Porto Cardoso G. M., Figueredo W. N. У розвідках (Кремень В. Г. \& Биков В. Ю., 2014, с. 10; Сучасні інформаційні технології та інноваційні методики навчання у підготовці фахівців, 2015; Харківська А., 2013) визначена необхідність впровадження нововведень, принципово нових підходів до розвитку освіти на всіх їі щаблях, що відповідають сучасному суспільному розвитку. Зазначено (Приходько В. В., 2010, с. 125), що успішність реалізації освітніх 
програм неможлива без використання ідей і положень модернізації у формуванні й реалізації їхнього змісту. Останнє питання залишається вельми значущим в аспекті забезпечення якості освітнього процесу.

Розуміння основних тенденцій розвитку освіти, відповідних сучасному суспільному розвитку, механізмів їхнього впровадження дає можливість для глибокого аналізу освітніх процесів, а відтак виявлення можливостей підвищення ефективності цього процесу та створення основ для успішної інтеграції вітчизняної системи освіти у європейський простір.

МЕТА І ЗАВДАННЯ ДОСЛІДЖЕННЯ - виявлення основних напрямів розвитку освіти в контексті модернізації на початку XXI століття.

\section{МЕТОДИ ДОСЛІДЖЕННЯ}

Для досягнення мети використано методи аналізу та синтезу, абстрагування, формалізації та ідеї інтенсивного впровадження інновацій в освітню галузь і концептуальних положень модернізації.

\section{РЕЗУЛЬТАТИ ДОСЛІДЖЕННЯ}

Передусім для проведення дослідження у визначеному ракурсі вважаємо слушним зазначити, що нині високий рівень якості освіти позиціонується як корелятор рівня життя, інструмент соціальної та культурної злагоди, економічного зростання (Кремень В. Г., 2004, с.17). Визначено (Porto Cardoso G. M., \& Figueredo W. N., 2013, c. 62), що освіта є стрижневим чинником розвитку країни. Освітня галузь відіграє важливу роль в економічній, культурній, соціальній та політичній сферах життєдіяльності суспільства. У XXI ст. розвиток освіти в контексті інноваційних процесів модернізації набуває особливого значення завдяки технологічному, науковому та економічному прогресу в усіх галузях знань.

Освіта завжди була осередком інноваційного поступу. Орієнтири переходу до нової освітньої парадигми передбачають переосмислення освітньої доктрини на рівні європейської якості, відповідну їй модернізацію змісту й оптимізацію його технологічного забезпечення для досягнення нової якості. Це цілком співзвучно із найактуальнішими тенденціями розвитку галузі: Міністерством освіти і науки України визначено та схвалило стратегічні напрями модернізації системи освіти з урахуванням міжнародного досвіду і вітчизняних реалій (Андрущенко В., 2008). Вважаємо, що кроком до розвитку освіти в такому напрямі $€$ впровадження міждисциплінарного й проектного підходів, що стає невід'ємним складником сучасної інноваційної парадигми освіти, тобто модернізації як наукової рефлексії, так і практики реалізації освіти загалом.

2014 року ухвалили Закон України «Про вищу освіту», що стало початком реформування освітньої галузі нашої держави. Цей документ запровадив багато змін, зокрема й щодо забезпечення якості вищої освіти як основного принципу Болонської декларації та пріоритету освітньої політики розвинутих європейських держав. Ми долучаємося до думки (Гуревич Р.С., Кадемія М. Ю., Козяр М. М., 2012; Приходько В. В., 2010), що зазначене вимагає розробки нової освітньої концепції, створення оновленої системи освіти, перехід від архаїчних методик до передових методів супроводу освітньої діяльності. Відтак це зумовлює необхідність докорінної зміни професійної діяльності й фахівців, оскільки їм доводиться працювати в ситуації перманентних нововведень. Акцентується (Кремень В. Г., 2004, с. 240) на необхідності їхнього професійного розвитку задля забезпечення високоякісних освітніх послуг та вдосконалення наукової, педагогічної, інноваційної діяльності.

Теоретичним узагальнюванням інформації (Андрущенко В., 2004, с. 8; Дубасенюк О. А., 2011, с. 140; Іщенко А. Ю.; Кремень В. Г., 2004, с. 55; Приходько В. В., 2010, с. 97) установлено, що сучасному стану розвитку освіти притаманні певні тенденції, серед яких: перехід від переважно інформаційних форм до активних методів і форм навчання; перехід до фасилітаційного способу навчання, який сприяє стимулюванню, розвитку, організації творчої, самостійної діяльності суб'єкта навчання; організація процесу навчання як спільної дії його учасників.

Аналізуючи спеціальну літературу в напрямі виокремлення характеристик та тенденцій міжнародного освітнього простору, серед яких глобалізація та інтернаціоналізація освіти, інтенсивний розвиток та широке використання інформаційно-комунікаційних технологій (IKT), реструктуризація ринку праці, професійна мобільність фахівця у вертикальному та горизонтальному вимірах, визначаємо необхідність забезпечення можливостей для продовження освіти на неперервній основі, що належить до пріоритетних завдань держави (Mukan N., Noskova M., \& Baibakova I., 2017, р. 124).

Глобалізаційні процеси на початку XXI ст. зумовлюють формування єдиного міжнародного освітнього простору, багатогранність якого забезпечується збереженням неповторності та унікальності освітніх систем різних країн. Ми підтримуємо положення (Андрущенко В., 2008; Іщенко А. Ю.; Харківська А., 2013) про інноваційність розвитку системи освіти, характерною особливістю якої $€$ висока якість освітніх послуг незалежно від часових та просторових чинників на основі сучасних тенденцій міжнародного освітнього простору. Сьогоденне суспільство потребує висококваліфікованих спеціалістів різних галузей господарства, здатних адаптуватися до викликів нового тисячоліття.

В означеному аспекті останнім часом у системі освіти все більшого поширення й обговорення набуває тема IKT, яка поєднує в собі міждисциплінарній підхід, підґрунтям для якого є інтеграція таких технологій у освітній процес. У визначеному аспекті виняткову актуальність набувають інновації у сфері освіти на усіх рівнях, скеровані на впровадження у їі поступ наукових досягнень і поширення передового досвіду інформатизації як чинника забезпечення ефективності освітнього процесу. Накопичений досвід освітніх інновацій 3 використання ІКТ у педагогічній науці, теорії й практиці є вагомим внеском у навчальні технології. Як і інші науковці (Биков В. Ю., 2010; Кремень В. Г. \& Биков В. Ю., 2014, с. 12), вважаємо, що необхідність такого виникає у зв'язку із упровадженням змін у зміст та технології освітнього процесу, що цілком співзвучно із Національною стратегією розвитку освіти в 
Україні на період до 2021 року, де визначено, що модернізація і розвиток освіти повинні набути випереджального неперервного характеру.

Інтеграція ІКТ в освітній процес створює передумови для кардинального оновлення як змістово-цільових, так і технологічних сторін навчання, що проявляється у суттєвому збагаченні системи дидактичних прийомів, засобів навчання і на цій основі формуванні нетрадиційних педагогічних технологій (Биков В. Ю., 2010).

Реалізація IKT в освітньому процесі з позицій і в контексті нашого дослідження, з одного боку - ідеї, засоби, методи, які є інноваційними, з іншого - інтеграція IKT спричинює зміну елементів педагогічного процесу, що забезпечує його модернізацію. Виконуючи функції інструментарію для розв'язання педагогічних завдань, використання IКT забезпечує якісно новий технологічний поступ у методиці і дидактиці, організації та практичній реалізації освітнього процесу. Водночас розвиток та модернізація освіти на основі інтеграції у цей процес ІКТ, створення умов для їхнього розроблення, апробації та впровадження, раціональне поєднання нових інформаційних технологій навчання 3 традиційними є надзвичайно складною педагогічною проблемою, що потребує перманентного дослідження.

Ще одним напрямом розвитку вищої освіти в контексті сучасних світових тенденцій її модернізації та на основі засадничих ідей педагогіки є врахування андрагогічних принципів навчання, серед яких - пріоритет самостійного навчання; принцип спільної діяльності; принцип опори на досвід учня-дорослого; індивідуалізації навчання; принцип системності навчання; принцип контекстності навчання; принцип актуалізації результатів навчання; принцип елективності навчання; принцип розвитку освітніх потреб; принцип свідомого навчання. Водночас відзначено (Приходько В. В., 2010, с. 152), що стимулюванню розвивальних процесів в освіті може сприяти використання інноваційних ідей, концептуальних положень щодо модернізації підходів до організації, формування і реалізації змісту занять. Передусім це стосується персоналістичного підходу до освіти й навчання, положень програмування занять та інтегративного підходу під час реалізації їхнього змісту.

Ще одним вагомим напрямом розвитку освіти, передбаченим новою освітньою парадигмою, є застосування в освітньому процесі типу соціокультурного наслідування від майбутнього до сучасного, тобто реалізація концепції «неперервного навчання», що трансформується в ідею неперервної освіти. Освіта перестає трактуватися як досягнення певного рівня знань, а розглядається з позицій «неперервності протягом життя». Одною із суттєвих сучасних ознак неперервної освіти $€$ неспроможність обмежити потребу в освіті певним, заздалегідь визначеним віком чи терміном, а тим більше рівнем (Mukan N., Noskova M., \& Baibakova I., 2017, р. 130). Адже безпрецедентно стрімке зростання наукових знань, швидке оновлення сучасної техніки, нових технологій, ускладнення, диверсифікованість соціальних ролей, високий темп морального старіння знань і техніки зумовлюють безупинне оволодіння новими знаннями, компетентностями, кваліфікаціями.

Сьогодні побудова ефективної системи освіти згідно з ідеєю «неперервного навчання» неможлива без створення та розроблення нових освітніх моделей, що забезпечують навчання як цілісний процес постійного вдосконалення особистості, поповнення її знань, умінь і навичок упродовж життя. Вивчення практики дозволяє стверджувати, що з кожним роком збільшується кількість інституцій, що створюють інноваційні освітні моделі: навчально-наукововиробничий комплекс, науково-освітній комплекс, навчально-виховний комплекс відповідно до українського законодавства.

Сьогодні простежуємо налагодження співпраці між вищою, загальноосвітньою школою і колежами з метою залучення до закладів вищої освіти обдарованої молоді; раннього профілювання учнів старшої школи; проектної організації для підготовки фахівців у системі ступеневої освіти; підготовки фахівців за наскрізними навчальними планами і програмами; спільного та ефективного використання матеріально-технічної бази; апробації та використання наукових досліджень; залучення учнів і студентів до науково-дослідної роботи; створення реальних умов для проходження практики та працевлаштування фахівців тощо.

Для досягнення визначеної мети розвивають такі форми співробітництва, як розробка спільної документації; створення комісії для розробки інтегрованих навчальних планів і програм; проведення спільної наукової роботи; створення системи підвищення кваліфікації та стажування; спільної навчально-методичної роботи; спільної організації виховних заходів; здійснення профорієнтаційної роботи тощо. Це зумовлює необхідність розвитку науки, подальшої розробки теоретико-методологічних основ неперервної професійної освіти з метою забезпечення ефективності професійного розвитку працівників освітньої галузі.

Розвиток освітньої галузі неможливо реалізувати без модернізації професійного поступу науково-педагогічних працівників університетів та вчителів загальноосвітніх шкіл, використання інструментарію оновлення знань педагогів, їхніх умінь і навичок; реформування освіти та поглиблення її змісту; розширення освітніх пропозицій згідно з вимогами сучасності. Увага політиків до проблеми професійного розвитку педагогів у системі неперервної педагогічної освіти, збільшення державного фінансування та приватних ініціатив свідчать про важливість цього питання. Формування висококваліфікованих педагогів, здатних діяти на рівні вимог міжнародних професійних стандартів, зумовлена контекстом входження України у світовий освітній простір (Кремень В. Г., 2004, с. 350).

На початку XXI ст. інтенсифікуються порівняльно-педагогічні дослідження, зокрема і в галузі професійного розвитку науково-педагогічних працівників університетів. Вони реалізуються на основі застосування таких концептів: аналітичного (характеристика системи неперервної педагогічної освіти країни), критичного (динаміка функціонування та реформування систем неперервної педагогічної освіти в дискурсі професійного розвитку викладачів університетів), прогностичного (застосування продуктивних ідей та досвіду досліджуваних країн у вітчизняній педагогічній теорії і практиці) та механізмів уніфікації й диверсифікації інформації, отриманої на основі опрацювання нормативно-правової бази та науково-педагогічних джерел. 
Професійний розвиток розглядається як неперервний процес ціложиттєвого навчання й розвитку, що починається на початкових етапах життя, триває під час навчання у закладі вищої освіти та після його завершення, а також - множинність різних видів діяльності, в якій педагоги самостійно чи колективно беруть участь 3 метою удосконалення фахової практики і заохочення студентів до навчання; це загальна сукупність формального та неформального навчального досвіду, що формується упродовж всієї кар'єри від початкової педагогічної освіти і до виходу на пенсію (Mukan N., Noskova M., \& Baibakova I., 2017, р. 127). Професійний розвиток передбачає підвищення професіоналізму педагогів, що ґрунтується на освоєнні професійних знань, формуванні фахового усвідомлення та ставлення, розвитку вмінь і навичок, компетентності. Він є саме тим процесом, за допомогою якого педагоги освоюють і розвивають власні знання, уміння й навички роботи з дітьми, учнівською молоддю, студентами, колегами на кожному етапі педагогічної кар'єри за умов системи неперервної педагогічної освіти.

Формування інформаційно-технологічного суспільства, докорінні зміни в соціально-економічному, духовному розвитку держави потребують підготовки педагога нової генерації. Необхідність інтеграції національної освіти в європейський освітній простір вимагає визначення концептуальних стратегій щодо подальшого вдосконалення та розвитку педагогічної освіти. Згідно з постулатами Концептуальних засад розвитку педагогічної освіти України, одним із основних завдань такого процесу є: модернізація освітньої діяльності закладів вищої педагогічної освіти, які здійснюють підготовку педагогічних і науково-педагогічних працівників. Необхідність упровадження інновацій у цей процес обґрунтовано низкою причин і недоліків традиційної технології навчання.

\section{ВИСНОВКИ ТА ПЕРСПЕКТИВИ ПОДАЛЬШИХ ДОСЛІДЖЕНЬ}

Питання розбудови національної системи освіти в сучасних умовах з урахуванням кардинальних змін у всіх сферах суспільного життя, історичних викликів XXI століття належить до глобальних, що безпосередньо пов'язане з реалізацією молодіжної та демографічної політики задля поступового руху українського суспільства до європейської спільноти. Підвищення якості освітнього процесу зумовлене дією низки чинників, у переліку яких важливе місце посідає розвиток освіти на основі модернізації. Активне впровадження модернізаційних технологій в освітній процес відповідне сучасному суспільному розвитку та $€$ найважливішим стратегічним пріоритетом сталого розвитку галузі.

Представлені результати наукового пошуку доповнюють ідеї щодо модернізаційних напрямів розвитку освіти, інноваційних підходів до організації, формування і реалізації змісту освітнього процесу. Найважливішою вимогою до системи освіти є те, що вона повинна за якістю не тільки відповідати вимогам практики, науки, соціальної сфери, але й мати випереджувальний характер.

За результатами наукового пошуку установлена об'єктивна необхідність інтеграції інноваційних технологій у процес професійної підготовки педагогічних кадрів. Реалізація виявлених напрямів розвитку освіти в контексті модернізації скерована на радикальні зміни, що матимуть вплив на розвиток освітнього процесу задля досягнення вищих навчальних результатів і формування якісно іншої освітньої практики.

Вважаємо, що потенціал модернізаційного розвитку освіти на всіх її щаблях залишається недостатньо розкритим, оскільки існує невідповідність між вимогами запитів освітньої практики значною мірою у зв'язку з необхідністю забезпечити високий рівень її ефективності і станом реалізації інновацій.

Проведене дослідження не вичерпує всіх аспектів проблеми. Напрями подальших досліджень вбачаємо передусім у виявленні особливостей модернізації освіти у європейських країнах, що дасть змогу проаналізувати її переваги та недоліки, співставити їх із традиціями вітчизняної педагогічної науки та зробити висновки щодо використання найкращих практик у системі освіти України.

\section{СПИСОК ВИКОРИСТАНИХ ДЖЕРЕЛ}

Андрущенко, В. (2004). Модернізація педагогічної освіти України в контексті Болонського процесу. Вища освіта України, 1, 5-9. Андрущенко, В. (2008). Інноваційний розвиток освіти в стратегії «українського прориву». Вища освіта України, 2.

Биков, В. Ю. (2010). Сучасні завдання інформатизації освіти. Інформаційні технології і засоби навчання, 1(15).

Гуревич, Р.С., Кадемія, М. Ю., \& Козяр, М.М. (2012). Інформаційно-комунікаційні технології в професійній освіті майбутніх фахівців / за ред. член-кор. НАПН України Гуревича Р. С. Львів : ЛДУ БЖД.

Дубасенюк, О.А. (2011). Розвиток вищої освіти: тенденції та перспективи. Людиноцентризм як основа гуманітарної політики України: освіта, політика, економіка, культура : матер. Всеукр. конф.: ІОД НАПН України, 135-142.

Іщенко, А. Ю. Глобальні тенденції і проблеми розвитку освіти: наслідки для України. Аналітична записка. Сайт Національного інституту стратегічних досліджень при Президентові України [Електронний ресурс]. - Режим доступу : http://www.niss.gov.ua/ articles/1537/

Кремень, В. Г., \& Биков, В. Ю. (2014). Інноваційні завдання сучасного етапу інформатизації освіти. Сучасні інформаційні технології та інноваційні методики навчання у підготовці фахівців: методологія, теорія, досвід, проблеми, 37, 3-15.

Кремень, В. Г. (2004). Освіта і наука в Україні - інноваційні аспекти. Стратегія. Реалізація. Результати: Монографія. Київ : Грамота.

Приходько, В. В. (2010). Інноваційна реформа вищої освіти в сучасній Україні. Дніпропетровськ : Пороги.

Сучасні інформаційні технології та інноваційні методики навчання у підготовці фахівців: методологія, теорія, досвід, проблеми (2015). Зб. наук. пр. Київ-Вінниця: ТОВ фірма «Планер», 471.

Національна стратегія розвитку освіти в Україні на період до 2021 року, схвалена Указом Президента України від 25 червня 2013 року №344/2013 / Офіційне інтернет-представництво Президента України. URL: http://www.president.gov.ua.

Про затвердження Концептуальних засад розвитку педагогічної освіти в Україні та її інтеграції в європейський освітній простір. Наказ Міністерства і науки № 988 від 31.12.04 року. URL. http: //o svita. ua/legislation/Vishya_osvita/3145/. 
Харківська, А. (2013). Управління інноваційним розвитком ВНЗ в умовах формування загальноєвропейського простору вищої освіти. Теорія та методика управління освітою, 13. URL: http://nbuv.gov.ua/UJRN/ttmuo_2013_13_12.

Porto Cardoso G. M., \& Figueredo W. N. (2013). Universidade e sociedade: o papel do professor na (re) construзго do conhecimento. Revista Intersaberes, 54-67. DOI: 10.22169.

Mukan, N., Noskova, M., \& Baibakova, I. (2017). The formation of school principals' readiness to use internet technologies in their work in the system of continuous pedagogical education, Наука і освіта, 4, 123-132.

\section{REFERENCES}

Andrushchenko, V. (2004). Modernizatsiia pedahohichnoi osvity Ukrainy v konteksti Bolonskoho protsesu. Vyshcha osvita Ukrainy, 1, 5-9.

Andrushchenko, V. (2008). Innovatsiinyi rozvytok osvity v stratehii «ukrainskoho proryvu». Vyshcha osvita Ukrainy, 2.

Bykov, V. Yu. (2010). Suchasni zavdannia informatyzatsii osvity. Informatsiini tekhnolohii i zasoby navchannia, 1(15).

Hurevych, R.S., Kademiia, M. Yu., \& Koziar, M.M. (2012). Informatsiino-komunikatsiini tekhnolohii v profesiinii osviti maibutnikh fakhivtsiv; za red. chlen-kor. NAPN Ukrainy Hurevycha R. S. Lviv : LDU BZhD.

Dubaseniuk, O.A. (2011). Rozvytok vyshchoi osvity: tendentsii ta perspektyvy. Liudynotsentryzm yak osnova humanitarnoi polityky Ukrainy: osvita, polityka, ekonomika, kultura : mater. Vseukr. konf.: IOD NAPN Ukrainy, 135-142.

Ishchenko, A. Yu. Hlobalni tendentsii i problemy rozvytku osvity: naslidky dlia Ukrainy. Analitychna zapyska. Sait Natsionalnoho instytutu stratehichnykh doslidzhen pry Prezydentovi Ukrainy [Elektronnyi resurs]. - Rezhym dostupu: http://www.niss.gov.ua/articles/1537/

Kremen, V. H., \& Bykov, V. Yu. (2014). Innovatsiini zavdannia suchasnoho etapu informatyzatsii osvity. Suchasni informatsiini tekhnolohii ta innovatsiini metodyky navchannia u pidhotovtsi fakhivtsiv: metodolohiia, teoriia, dosvid, problemy, 37, 3-15.

Kremen, V. H. (2004). Osvita i nauka v Ukraini - innovatsiini aspekty. Stratehiia. Realizatsiia. Rezultaty: Monohrafiia. Kyiv : Hramota.

Prykhodko, V. V. (2010). Innovatsiina reforma vyshchoi osvity v suchasnii Ukraini. Dnipropetrovsk : Porohy.

Suchasni informatsiini tekhnolohii ta innovatsiini metodyky navchannia u pidhotovtsi fakhivtsiv: metodolohiia, teoriia, dosvid, problemy (2015). Zb. nauk. pr. Kyiv-Vinnytsia: TOV firma «Planer».

Natsionalna stratehiia rozvytku osvity v Ukraini na period do 2021 roku, skhvalena Ukazom Prezydenta Ukrainy vid 25 chervnia 2013 roku №344/2013 / Ofitsiine internet-predstavnytstvo Prezydenta Ukrainy. Retrieved from: http://www.president.gov.ua.

Pro zatverdzhennia Kontseptualnykh zasad rozvytku pedahohichnoi osvity v Ukraini ta yii intehratsii v yevropeiskyi osvitnii prostir. Nakaz Ministerstva i nauky № 988 vid 31.12.04 roku. Retrieved from: http: //o svita. ua/legislation/Vishya_osvita/3145/.

Kharkivska, A. (2013). Upravlinnia innovatsiinym rozvytkom VNZ v umovakh formuvannia zahalnoievropeiskoho prostoru vyshchoi osvity. Teoriia ta metodyka upravlinnia osvitoiu, 13. Retrieved from: http://nbuv.gov.ua/UJRN/ttmuo 2013 13 12.

Porto Cardoso G. M., \& Figueredo W. N. (2013). Universidade e sociedade: o papel do professor na (re) construção do conhecimento. Revista Intersaberes, 54-67. DOI: 10.22169.

Mukan, N., Noskova, M., \& Baibakova, I. (2017). The formation of school principals' readiness to use internet technologies in their work in the system of continuous pedagogical education. Science and Education, 4, 123-132. 